\title{
Study the Antibacterial Activity of Bacteriocin Produced from the Locally Isolated Cronobacter sakazakii
}

\author{
Hameed M. Jasim*, Nedhaal S. Zbar and Mahaba R. Al-Roubaiee \\ Department of Biotechnology, Al-Nahrain University, Baghdad-Iraq. \\ Corresponding Author:-maysmays9510@gmail.com.
}

\begin{abstract}
Cronobacter sakazakii was isolated from food samples and identified using morphological, biochemical tests and VITEK-2 system to produce bacteriocin by induction with mitomycin-C. C.sakazakii isolates were screened for their ability for bacteriocin production. Result showed that all these isolates were bacteriocin producers, but the most efficient isolate was MA7. Antibacterial activity of bacteriocin against some pathogenic bacteria was tested using well diffusion method. Bacteriocin was partially purified by ammonium sulfate precipitation, ion exchange using (DEAE)Cellulose. After purification steps, three peaks were obtained. quantitative screening of bacteriocin involving the estimation of protein concentration and estimation of antibacterial activity showed that the large first peak was $1.6 \mathrm{mg} / \mathrm{ml}, 640 \mathrm{U} / \mathrm{ml}$. [DOI: 10.22401/JNUS.21.2.17]
\end{abstract}

Keywords: Cronobacter sakazakii, Bacteriocin, Purification.

\section{Introduction}

The rapid increase in drug-resistant infections has presented a serious challenge to antimicrobial therapies. The failure of the most potent antibiotics to kill "superbugs" emphasizes the urgent need to develop other control agents. Natural antimicrobial peptide can be found in prokaryotes such as bacteria and eukaryotes such as fungi, insects, plants, protozoan and animals [1]. They are of great interest to medicine, pharmacology, and the food industry. These peptides are capable of inhibiting pathogenic microorganisms. They can attack parasites, while causing little or no harm to the host cell. A substance to be deemed as a useful chemotherapeutic agent must have toxic selectivity for the parasite, i.e., at an effective concentration in tissue the substance must have low toxicity to host cells and high toxicity to the infective agent, it also should not alter the natural defense mechanisms of the host, such as phagocytosis and synthesis of antibodies [2]. C. sakazakii belongs to the genus Cronobacter, and as most species in this genus, it is considered an opportunistic pathogen. C. sakazakii is Gramnegative, oxidase-negative, non spore forming, non-acid-fast, straight, rod-shaped bacteria and $1 \mu \mathrm{m} \times 3 \mu \mathrm{m}$ in size, it is motile by peritrichous flagella, non-halophilic, facultative anaerobic [3]. Bacteriocins are antimicrobial peptides with different sizes, microbial target and mechanisms of action produced by large variety of bacteria. They are characterized by a bactericidal or bacteriostatic activity against strains of the same species or closely related species and differ from most therapeutic antibiotics due to their narrow activity spectrum and their proteinaceous nature[4]. Many bacteriocins have been described and classified, but only a few of them have been studied in detail, therefore this study was aimed to Isolate and identify $C$. sakazakii from different food sources, partially purify bacteriocin produced by $C$. sakazakii and test its antibacterial activity against different strains of $C$. sakazakii and some pathogenic bacteria.

\section{Materials and Methods \\ Test microorganisms}

Pathogenic bacteria (Escherichia coli, Staphylococcus aureus, Klebsiella penumoniae, Shigella dysenteriae, Proteus vulgaris, Serratia marcescens) were supplied from Al-Zafaraniyah General Hospital.

\section{Isolation and identification of $\boldsymbol{C}$. sakazakii}

Isolation of $C$. sakazakii was done according to the method described by [5]. Seventy six samples of food materials were collected from Iraqi local markets. Food samples $(1,10,100) \mathrm{g}$ were added to $(9,90$, 900) $\mathrm{ml}$ of peptone water respectively and mixed thoroughly and incubated for $1 \mathrm{hr}$ at $37^{\circ} \mathrm{C}$. Then $10 \mathrm{ml}$ of each sample was 
resuspended in $90 \mathrm{ml}$ of Enterobacter Enrichment broth (EE) and incubated overnight at $37^{\circ} \mathrm{C}$. Then a loopful of each culture broth was streaked onto Violate Red Bile Glucose Agar (VRBGA) plates and incubated overnight at $37^{\circ} \mathrm{C}$. Dark pink or purple colonies were streaked on tryptic soy agar and incubated for $48-72 \mathrm{hrs}$ at $25^{\circ} \mathrm{C}$. Yellow pigmented colonies were selected for identification, streaked on Enterobacter sakazaki Agar (DFI) and incubated at $44^{\circ} \mathrm{C}$ for $24 \mathrm{hrs.}$

\section{Induction and extraction of bacteriocin production}

Brain heart infusion broth (BHI) was distributed in test tubes then inoculated with fresh culture of $C$. sakazakii and incubated at $37^{\circ} \mathrm{C}$ for $24 \mathrm{hrs}$ with shaking at $200 \mathrm{rpm}$. One $\mathrm{ml}$ of overnight culture was transferred to 500 $\mathrm{ml}$ conical flasks containing $100 \mathrm{ml}$ of BHI broth medium, incubated at $37^{\circ} \mathrm{C}$ with shaking at $200 \mathrm{rpm}$ for 2-3 hrs. Optical density of each culture was recorded by spectrophotometer at $600 \mathrm{~nm}$ to reach between 0.3 and 0.4. One $\mathrm{ml}$ of Mitomycin-C stock solution was added to each $100 \mathrm{ml}$ culture to have $1 \mu \mathrm{g} / \mathrm{ml}$ as a final concentration of Mitomycin-C. Culture were incubated for $2-5 \mathrm{hrs}$ at $37^{\circ} \mathrm{C}$ with shaking (200 rpm), then $700 \mu \mathrm{l}$ of chloroform was added to $100 \mathrm{ml}$ of each culture, transferred to sterile tube and vortexed for $15 \mathrm{~s}$ followed by then centrifugation at $4^{\circ} \mathrm{C}(7000 \mathrm{rpm} / 10 \mathrm{~min})$. Supernatant was filtered by Millipore filter and transferred to a sterile vial and stored in refrigerator at $4-0^{\circ} \mathrm{C}$.

\section{Antagonistic interactions between Cronobacter sakazakii isolates}

In order to select the more efficient isolate of $C$. sakazakii, well diffusion method [6] was used to test the ability of $C$. sakazakii isolates to inhibit the growth of each other. Brain heart infusion broth was used for propagation of all isolates identified as $C$. sakazakii and incubated at $37^{\circ} \mathrm{C}$ for $24 \mathrm{hrs}$. Then $100 \mu \mathrm{L}$ of culture of $C$. sakazakii isolates were taken and spread on BHI agar plates. Immediately wells was made in the medium using sterile cork borer and wells were filled with $100 \mu$ of crude filtrate of the $C$. sakazaki isolates. Plates were incubated at $37^{\circ} \mathrm{C}$ for $24 \mathrm{hrs}$. The inhibitory effect of bacteriocin was measured using the diameter of clear circular inhibition zones surrounding bacteriocin extract.

\section{Antagonistic reactions between Cronobacter sakazakii and pathogenic bacteria}

The antibacterial activity of bacteriocin produced by selected isolate of C. sakazakii was studied by detection the inhibitory effect of bacteriocin against $E$. coli, $S$. aureus, $K$. penumoniae, $S$. dysenteriae, $P$. vulgaris and $S$. marcescens, grown on BHI agar plates. The antagonistic effect against the test microorganism was done according to the well diffusion assay method described by [6] as follows: Brain heart infusion broth was inoculated with fresh culture of test microorganism (E. coli, $S$. aureus, $K$. penumoniae, $S$. dysenteriae, $P$. vulgaris and S.marcescens) and incubated at $37^{\circ} \mathrm{C}$ for 24 hrs. Then $100 \mu \mathrm{L}$ of overnight culture of test microorganisms was taken and spread on BHI agar plates by sterile cotton swabs. Immediately wells were made in the medium using sterile cork borer and filled with $100 \mu \mathrm{l}$ of crude filtrate of the $C$. sakazakii. Plates were incubated at $37^{\circ} \mathrm{C}$ for $24 \mathrm{hrs}$. The inhibitory effect of bacteriocin measured using the diameter of inhibition zones around bacteriocin extract.

\section{Partial purification of bacteriocin.}

The first step of bacteriocin purification was achieved by precipitation with ammonium sulphate. This was done by production of bacteriocin by $C$. sakazakii MA7 under the optimum conditions, then cultures were centrifuged at $7000 \mathrm{rpm}$ for $20 \mathrm{~min}$ at $4^{\circ} \mathrm{C}$. Ammonium sulfate was added to the supernatant (crude bacteriocin ) with gradual saturation ratios ranging between 20 to $60 \%$. After the addition of ammonium sulfate to crude bacteriocin at each saturation ratio, the mixture was mixed gently on magnatic stirrer at $4^{\circ} \mathrm{C}$ for $40-60 \mathrm{~min}$, then centrifuged at $4^{\circ} \mathrm{C}$ (10000 rpm/15 min). Supernatant was discarded and precipitated proteins were dissolved in a suitable volume of $0.05 \mathrm{M}$ Tris buffer at $\mathrm{pH}$. Bacteriocin activity and protein concentration were estimated before and after ammonium sulfate precipitation, then dialyzed at $4^{\circ} \mathrm{C}$ for overnight against the same buffer solution with three increments of substitutions. The dialyzed bacteriocin was passed through 
DEAE-cellulose column, then eluted with $\mathrm{NaCl}\left(0.1,0.2,0.3,0.4\right.$, and $\left.0.5 \mathrm{mg}^{-\mathrm{ml}^{-1}}\right)$. Protein concentration in each fraction was monitored spectrophotometrically at $280 \mathrm{~nm}$. Fractions of the peaks were assayed for bacteriocin activity. Fractions containing bacteriocin activity were collected and stored in refrigerator for future application. Bacteriocin activity, concentration and specific activity were estimated before and after each steps of purification according to Mesa-Pereira et al. [7], Bradford [8], and Whitaker and Bernard [9] respectively. Finally, antibacterial activity of partially purified bacteriocin against test microorganisms was tested by well diffusion method.

\section{Results and Discussion}

Out of seventy six samples, eighty six bacterial isolates were obtained and streaked on Violate Red Bile Glucose Agar (VRBGA) and incubation at $37^{\circ} \mathrm{C}$ for $24 \mathrm{hrs}$. Result showed that fifty one bacterial isolates were grown on VRBGA and gave dark pink colonies surrounded by pink halo [10]. Violate Red Bile Glucose Agar medium promote the growth of Enterobacteriaceae only and inhibits the growth of other bacteria because this medium contains Crystal Violet and blie salt in addition to Brilliant green. Fifty one bacterial isolates were streaked on Tryptone soy agar (TSA) and incubated at $25{ }^{\circ} \mathrm{C}$ for $48-72 \mathrm{hrs}$. Results showed that thirty bacterial isolates gave yellow colonies which identified on Enterobacter sakazaki Agar (DFI) and gave blue-green pigmented colonies and these result compatible with Iversen et al. [11]. After microscopic examination, results also showed that these isolates were gram negative, rod shaped, non spore forming, bacteria which coincided with result of Kandhai et al. [3]. Final identification of tested isolates were confirmed by using VITEK-2 identification system. Only seven isolates were identified as C. sakazakii and one isolate was identified as $C$. universalis which was obtained from Novalac powder milk. The other seven isolates identified as $C$. sakazakii were obtained from Dialac powder milk, and one from each source: mixed salad vegetables, Raw meat, Nactalia powder milk, Celia powder milk and Novalac Powder milk. These seven isolates were designated as MA4, MA7, MA16, MA28, MA31, MA45, MA67.

\section{Antagonistic reactions between $C$. sakazakii isolates}

In order to select efficient isolate of $C$. sakazakii, Well diffusion method was used to test the ability of $C$. sakazakii isolates to inhibit the growth of each other. The ability of these isolates in bacteriocin production was assayed after culturing in BHI broth medium at $37^{\circ} \mathrm{C}$ and incubated until optical density was reached (0.3-0.4). Crude bacteriocin in culture filtrate was used to study the antagonistic interaction against each other by measuring the inhibition zones according to the well diffusion method. Results in Table (1) showed that MA7 was most efficient isolate of $C$. sakazakii in bacteriocin production according to the inhibition zones against other $C$. sakazakii isolates. Which gave the maximum diameter zone of inhibition $(13 \mathrm{~mm})$ against MA16 isolate. This result agreed with De Graaf and Klaasen, [12] who found that cloacin DF13 that produced from Enterobacter cloacae was very effective killing activity against sensitive strains of the same bacterial species. 
Table (1)

Ability of local isolats of $C$. sakazakii in bacteriocin production specified by inhibition zones against each others.

\begin{tabular}{|c||c|c||c|c||c||c||c|}
\hline C. sakazakii isolates & MA4 & MA7 & MA16 & MA28 & MA31 & MA45 & MA67 \\
\hline \hline MA4 & - & $5 \mathrm{~mm}$ & $6 \mathrm{~mm}$ & $5 \mathrm{~mm}$ & - & $5 \mathrm{~mm}$ & $5 \mathrm{~mm}$ \\
\hline MA7 & $7 \mathrm{~mm}$ & - & $13 \mathrm{~mm}$ & - & $8 \mathrm{~mm}$ & $6 \mathrm{~mm}$ & $9 \mathrm{~mm}$ \\
\hline MA16 & - & - & - & - & - & - & - \\
\hline \hline MA28 & - & - & $5 \mathrm{~mm}$ & - & - & $5 \mathrm{~mm}$ & - \\
\hline \hline MA31 & $5 \mathrm{~mm}$ & - & $5 \mathrm{~mm}$ & $7 \mathrm{~mm}$ & - & - & - \\
\hline \hline MA45 & - & - & $5 \mathrm{~mm}$ & - & $6 \mathrm{~mm}$ & - & - \\
\hline MA67 & $5 \mathrm{~mm}$ & - & $5 \mathrm{~mm}$ & $6 \mathrm{~mm}$ & $5 \mathrm{~mm}$ & - & $6 \mathrm{~mm}$ \\
\hline
\end{tabular}

mm (diameter of inhibition zone)

-(non-detectable)

According to these results, MA7 isolate was selected to study antagonistic reaction against different pathogenic bacteria in addition to study the optimum condition for bacteriocin production.

Antagonistic reactions between Cronobacter sakazakii and pathogenic bacteria

Screening for bacteriocin production by $C$. sakazakii was achieved by detection the antagonistic effect of these isolate against test microorganisms. Results in Fig.(1) showed that bacteriocin produced by $C$. sakazakii have the antibacterial activity according to the inhibition zones against $E$. coli, $S$. aureus, $K$. penumoniae, S.dysenteriae, $P$. vulgaris and S.marcescens. The maximum inhibition zone was observed in S. aureus as shown in Fig.(2). Diameters of inhibition zones were ranged between 15 and $27 \mathrm{~mm}$. Graaf et al. [13] found that Enterobacter cloacae produces a bacteriocin with killing action on a sensitive strains or related bacterial species.

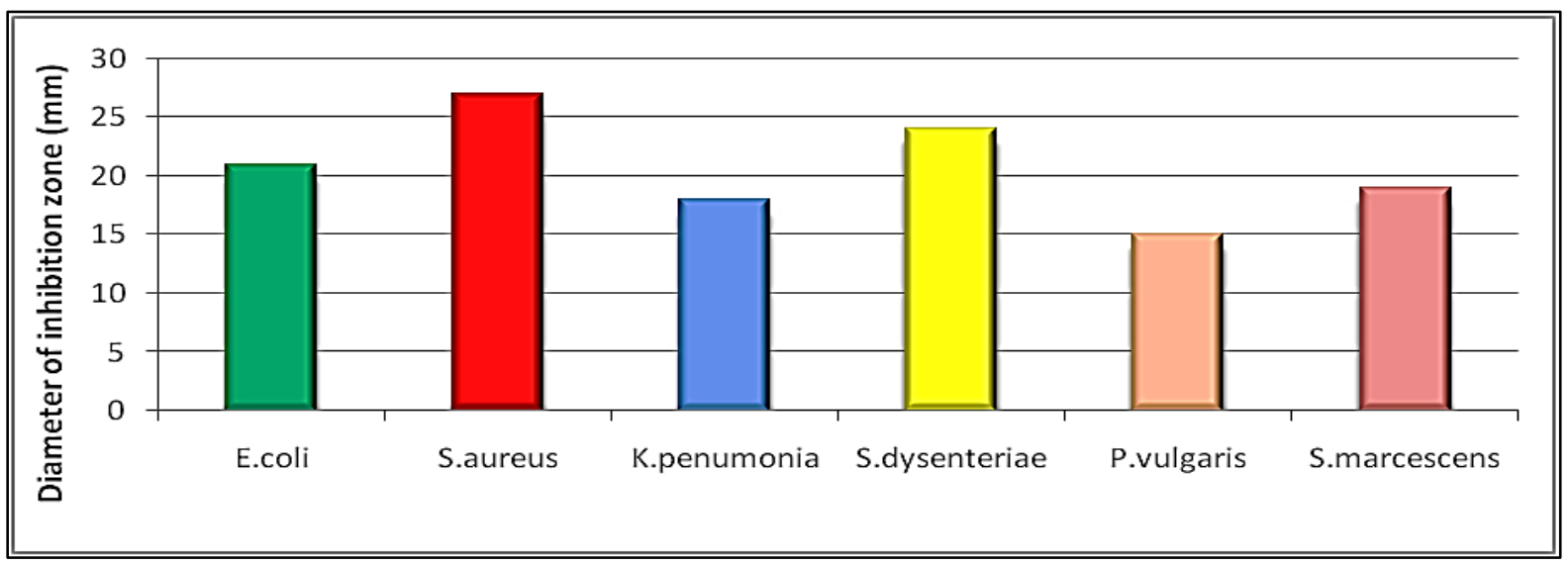

Fig.(1): Ability of C. Sakazakii in bacteriocin production specified by inhibition zones against test microorganisms. 


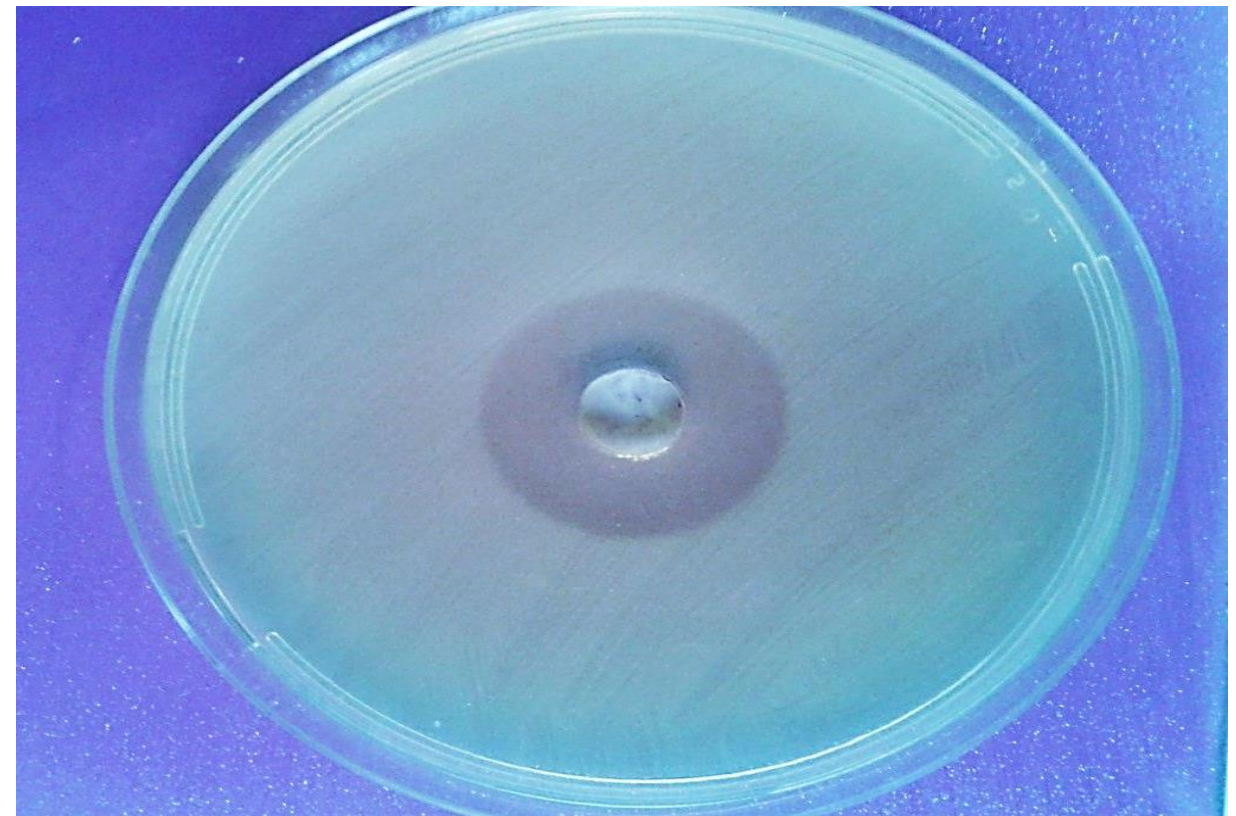

Fig.(2) : Inhibitory effect of bacteriocin produced by locally isolated C.Sakazakii MA7 against S. aureus on brain heart infusion agar medium after incubation at $37^{\circ} \mathrm{C}$ for $24 \mathrm{hrs}$.

Partial purification of bacteriocin.

In this study, ammonium sulphates was used in a gradual saturation ratio ranging between 20 and $40 \%$. Precipitated bacteriocin reaches its maximal activity $(36 \mathrm{~mm})$ at the saturation of $40 \%$ of the ammonium sulphate as shown in Fig.(3). Protein precipitation using ammonium sulphate depends on the salting out phenomenon. Salting out removes proteins that easily aggregate from those that are very soluble making it a good initial purification step for small soluble proteins. Ammonium sulfate, $\left(\mathrm{NH}_{4}\right)_{2} \mathrm{SO}_{4}$, is often used for salting out because of its high solubility, which allows for solutions of very high ionic strength, low price, and availability of pure material. Additionally, $\left(\mathrm{NH}_{4}\right)_{2}$ and $\mathrm{SO}_{4}$ are at the ends of their respective Hofmeister series and have been shown to stabilize protein structure [14].

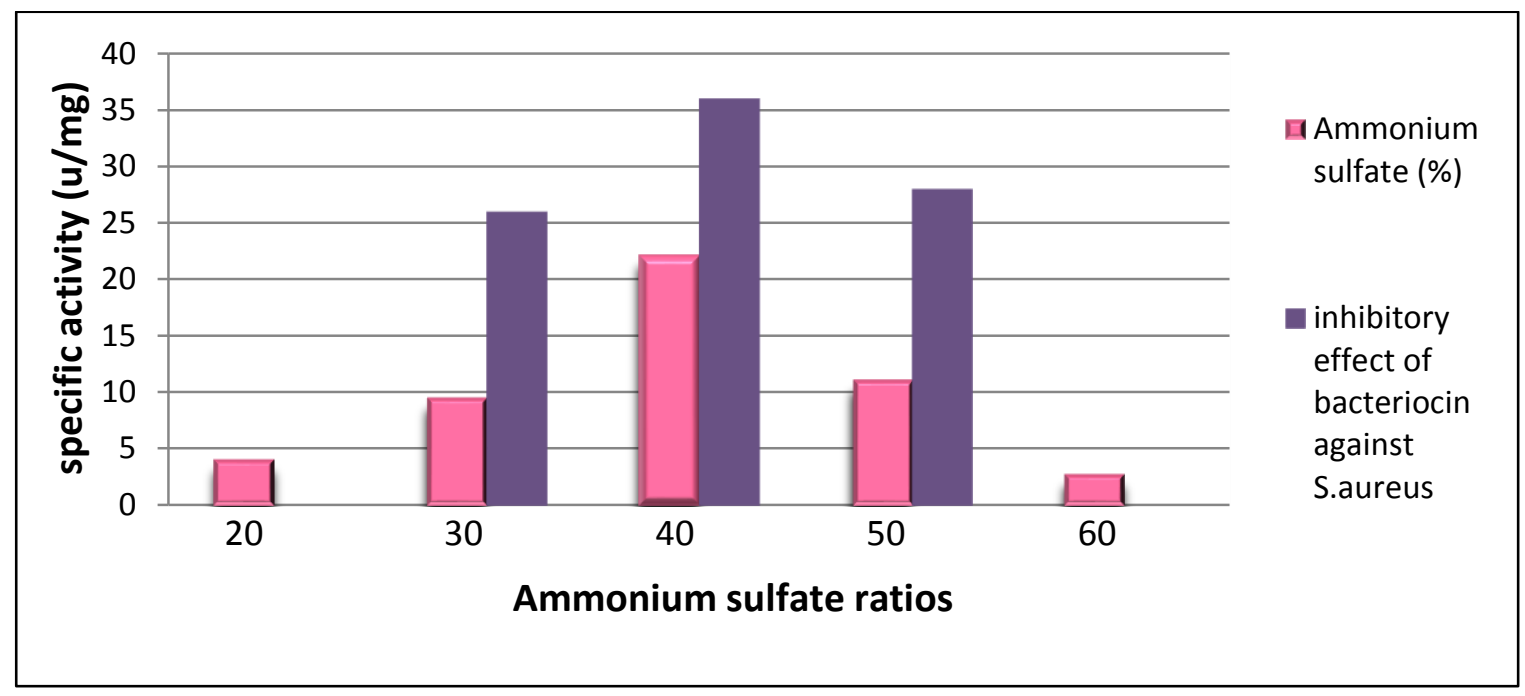

Fig.(3): Specific activity of bacteriocin produced by C.Sakazakii MA7 isolate after precipitation with different ammonium sulfate saturation ratios. 
Ion exchange chromatography technique was used to purify bacteriocin produced by locally isolated $C$. sakazakii after ammonium sulfate precipitation and dialysis step. In this technique, the dialyzed bacteriocin was applied to DEAE-cellulose column, then the column was equilibrated and washed with an equal volume of $0.05 \mathrm{M}$ Tris-buffer solution $(\mathrm{pH}$ 7) to wash uncharged and positively charged proteins in bacteriocin sample. The bound proteins (negatively charged) were then eluted using gradient concentrations of sodium chloride which ranged between 0.1 and $0.5 \mathrm{M}$. Results in Fig.(4) showed that there was one protein peaks appeared in washing step, while there were three protein peaks appeared by the gradient concentrations of sodium chloride. All these four protein peaks were detected by measuring the absorbance at $280 \mathrm{~nm}$ of each eluted fraction. Results in Table (2) showed that the first peak of the three eluted protein (fraction number 22 to 34) have bacteriocin activity reached to $640 \mathrm{U} / \mathrm{ml}$ while the other fraction were pooled and activity were measured. Antibacterial activity of partially purified bacteriocin was measured by well diffusion method. Results in Fig.(5) showed that the activity of bacteriocin increased when it partially purified. The maximum inhibition zone was observed in $S$. aureus. Diameters of inhibition zones were ranged between 21 and $41 \mathrm{~mm}$.

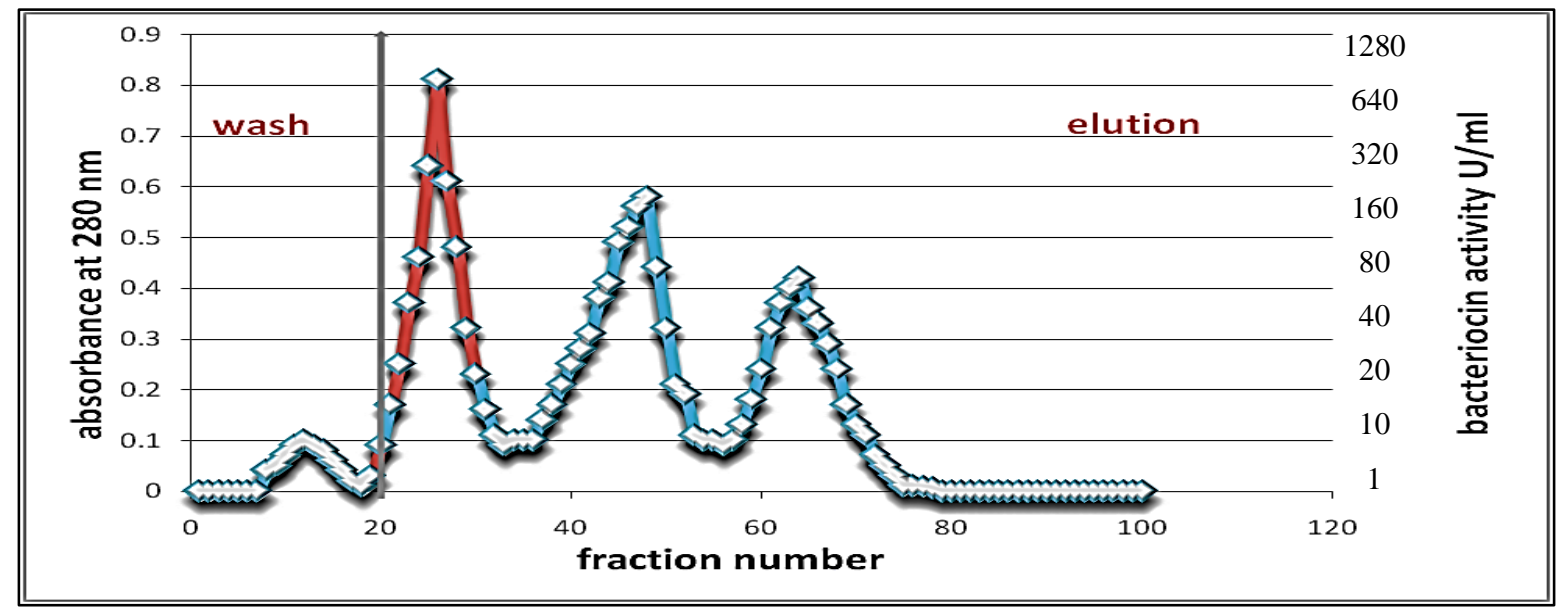

Fig.(4): Partial purification result of bacteriocin produced by Cronobacter sakazakii.

Table (1)

Partial Purification steps for bacteriocin produced by C. sakazakii

\begin{tabular}{||c||c||c||c|c||c|c|}
\hline $\begin{array}{c}\text { Steps of } \\
\text { Partial Purification }\end{array}$ & $\begin{array}{c}\text { Volume } \\
(\mathbf{m l})\end{array}$ & $\begin{array}{c}\text { Activity } \\
(\mathbf{U} / \mathbf{m l})\end{array}$ & $\begin{array}{c}\text { Protein } \\
\text { Conc. } \\
(\mathbf{m g} / \mathbf{m l})\end{array}$ & $\begin{array}{c}\text { Total } \\
\text { Activity } \\
(\mathbf{U})\end{array}$ & $\begin{array}{c}\text { Specific } \\
\text { Activity } \\
(\mathbf{U} / \mathbf{m g})\end{array}$ & $\begin{array}{c}\text { Yields } \\
(\mathbf{\%})\end{array}$ \\
\hline \hline Crude Extract & 100 & 40 & 5.2 & 4000 & 7.69 & 100 \\
\hline $\begin{array}{c}40 \% \text { Ammonium } \\
\text { Sulfate Saturation }\end{array}$ & 50 & 80 & 3.6 & 3200 & 22.2 & 80 \\
\hline Dialysis & 17 & 160 & 2.7 & 2720 & 59.25 & 68 \\
\hline $\begin{array}{c}\text { Ion exchanger } \\
\text { DEAE-cellulose }\end{array}$ & 13 & 640 & 1.6 & 8320 & 400 & 2.08 \\
\hline
\end{tabular}




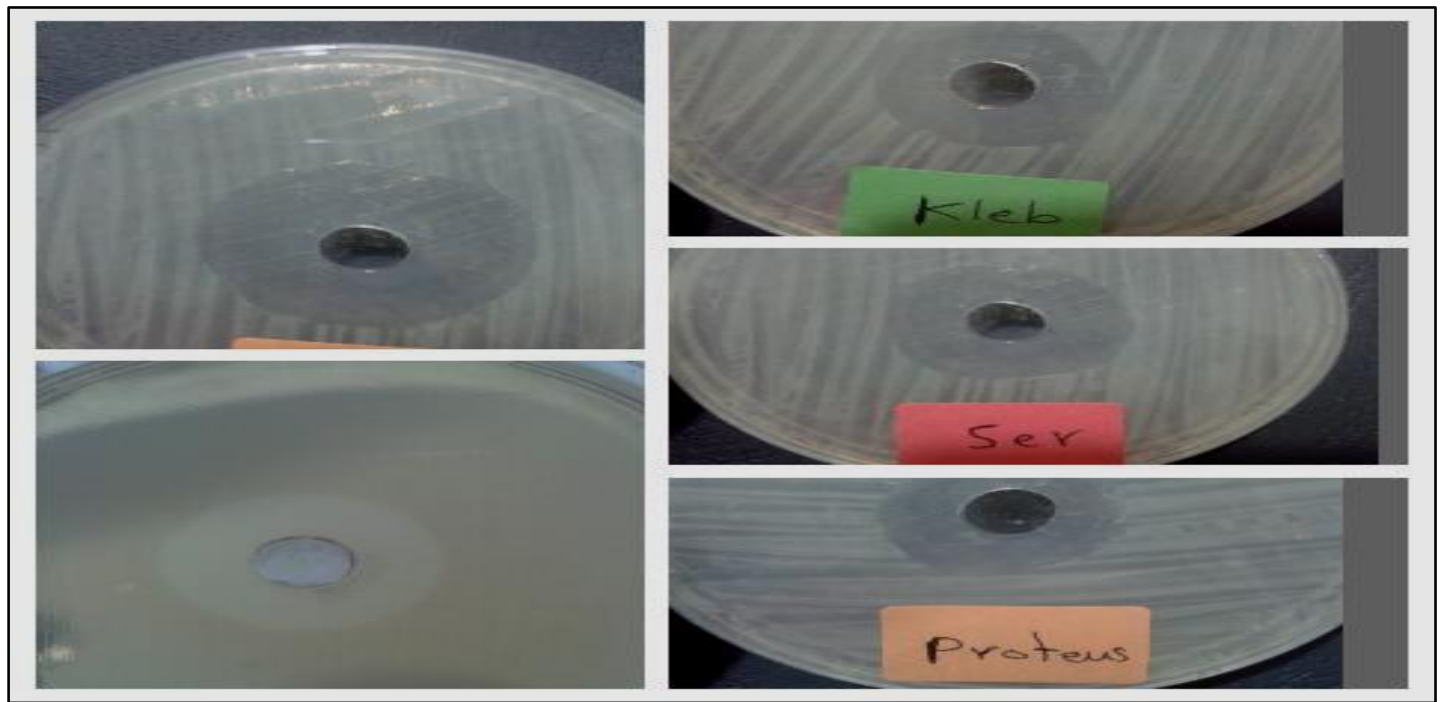

Fig.(5): Inhibitory effect of partially purified bacteriocin produced by locally isolated C.sakazakii MA7 against pathogenic bacteria.

\section{References}

[1] Conlon, J. M., and Sonnevend, A. (2010). Antimicrobial peptides in frog skin secretions. Antimicrobial Peptides: Methods and Protocols, 3-14.

[2] Coutinho, H. D. M., Lobo, K. M., Bezerra, D. A. C., and Lobo, I. (2008). Peptides and proteins with antimicrobial activity. Indian journal of pharmacology, 40(1), 3 .

[3] Kandhai, M. C., Reij, M. W., Grognou, C., Van Schothorst, M., Gorris, L. G. M., and Zwietering, M. H. (2006). Effects of preculturing conditions on lag time and specific growth rate of Enterobacter sakazakii in reconstituted powdered infant formula. Applied and environmental microbiology, 72(4), 2721-2729.

[4] Riley, M. A., and Chavan, M. A. (2007). Bacteriocins. Springer-Verlag Berlin Heidelberg.

[5] Food, F. D. A. (2003). Drug Administration, Isolation and enumeration of Enterobacter sakazakii from dehydrated powdered infant formula.

[6]Todorov, S. D., and Dicks, L. M. (2009). Bacteriocin production by Pediococcus pentosaceus isolated from marula (Scerocarya birrea). International Journal of Food Microbiology, 132(2), 117-126.

[7] Mesa-Pereira, B., O’Connor, P. M., Rea, M. C., Cotter, P. D., Hill, C., and Ross, R. P. (2017). Controlled functional expression of the bacteriocins pediocin PA-1 and bactofencin A in Escherichia coli. Scientific Reports, 7.

[8] Bradford, M. M. (1976). A rapid and sensitive method for the quantitation of microgram quantities of protein utilizing the principle of protein-dye binding. Analytical biochemistry, 72(1-2), 248-254.

[9] Whitaker, J. R., and Bernhard, R. A. (1972). Experiments for an Introduction to Enzymology. Whiber Press.

[10] Druggan, P., and Iversen, C. (2009). Culture media for the isolation of Cronobacter spp. International journal of food microbiology, 136(2), 169-178.

[11] Iversen, C., Lehner, A., Mullane, N., Bidlas, E., Cleenwerck, I., Marugg, J., and Joosten, H. (2007). The taxonomy of Enterobacter sakazakii: proposal of a new genus Cronobacter gen. nov. and descriptions of Cronobacter sakazakii comb. nov. Cronobacter sakazakii subsp. sakazakii, comb. nov., Cronobacter sakazakii subsp. malonaticus subsp. nov., Cronobacter turicensis sp. nov., Cronobacter muytjensii sp. nov., Cronobacter dublinensis sp. nov. and Cronobacter genomospecies 1. BMC evolutionary biology, 7(1), 64.

[12] De Graaf, F. K., and Klaasen- Boor, P. (1977). Purification and characterization of a complex between cloacin and its immunity protein isolated from Enterobacter cloacae (Clo DF13). The FEBS Journal, 73(1), 107-114.

[13] Graaf, F. D., Spanjaerdt Speckman, E. A., and Stouthamer, A. H. (1969). Mode of action of a bacteriocin produced by Enterobacter cloacae DF 13. Antonie van Leeuwenhoek, 35(1), 287-306.

[14] Burgess, R. R. (2009). Protein precipitation techniques. Methods in enzymology, 463, 331342. 